\title{
PDGFRB Gene Mutation
}

National Cancer Institute

\section{Source}

National Cancer Institute. PDGFRB Gene Mutation. NCI Thesaurus. Code C128172.

A change in the nucleotide sequence of the PDGRFB gene. 